\title{
Career crises
}

\section{The past year's postdoc journal keepers face familiar dilemmas, writes Gene Russo.}

The members of the punk-rock band The Clash surely didn't have science careers in mind when they wrote their 1982 song Should I Stay or Should I Go? Nevertheless, its sentiment resonates with thousands of fledgling scientists worldwide.

The question comes up routinely: should I stay in academia, where the competition is fierce and prospects are uncertain? Or should I venture out into the world of industry, or perhaps into a non-traditional science career, for a shot at better job security, job satisfaction and more pay? The postdocs who documented their career paths for last year's Naturejobs Postdoc Journal perfectly illustrated this dilemma (see http:// www.nature.com/naturejobs/archive/ postdocj/2009.html). The song's lyrics tell their tales.

\section{If I go there will be trouble}

Journal keeper Joanne Isaac left Australia and her postdoc position to follow her husband and his postdoc opportunity in Colorado. She has had trouble learning how not to be a postdoc. Isaac sometimes has felt frustrated, as she devoted most of her time to nurturing her toddler rather than her career. But she has started freelance science writing and has begun to appreciate the extra mum-time and the flexibility that this new-found profession affords. "While I baulk at using the old cliché 'like a phoenix from the ashes', it seems an apt description of my changing outlook," she writes. Isaac says she has been heartened by the several e-mails she has received from postdocs facing similar career twists.

\section{If I stay it will be double}

Julia Boughner and Bryan Venters, meanwhile, still cling to dreams of success in academia, but fear that staying could be more problematic than moving on. Boughner knows full well the long odds; and the demands of her young family make success even harder to achieve. She spent a considerable amount of time this year examining alternatives such as consulting, science outreach and freelance science writing.

And despite having what he considers a productive year - he presented his work at a meeting, wrote a review and published a paper — and a largely enjoyable lab experience,
Venters is leaning towards pursuing a job in industry or the government. Although he cherishes the collaborative academic environs, he longs for full-time employment. To be serious about an academic position, he figures he would need to spend another three or four years as a postdoc, and with the attendant personal and financial sacrifices.

\section{I'll be here 'til the end of time}

Sam Walcott also continues to work towards a job in academia, but his application process has been an exercise in frustration. His efforts have not been entirely useless - he says he has learned what sort of faculty positions to pursue, how to write a job application and how to approach an interview. But he worries that his funding will run out long before he receives that much-awaited offer.

Many postdocs share these journeys of self-discovery. Career decisions bring both discouragement and opportunity. But, as always, investigating all the options, no matter how nerve-wracking, offers the best chance of a successful move.

Gene Russo is the editor of Naturejobs.

\section{NEWS}

\section{Spanish reform will help foreign researchers}

Spain is making it easier for researchers living outside the European Union (EU) to work in the country, in line with a 2005 EU-wide directive. The Spanish government has now incorporated the scientific visa directive into its immigration law, which should accelerate visa approval for researchers.

The reform, which came into effect on 13 December, puts an end to a legal dispute between the European Commission and Spain, which had been slow to enact an EU-wide directive stating that member countries must put in place regulations to streamline the admission of foreign scientists. The Commission took Spain to the European Court of Justice in October 2008 after the country missed the October 2007 deadline. The delays were largely because modification of Spain's immigration law requires a difficult and time-consuming process of parliamentary consideration and congressional approval.

The changes include a special entry system for non-EU scientists that allows applicants to avoid the slow and cumbersome process of applying via the consulate. As part of a 'hosting agreement', scientists will be automatically granted visas if their hiring institution is accredited by the Spanish government and the job offer is for longer than one year.

The reform also provides an avenue to enter the country on a work permit, via the EU 'blue card'. Available for highly skilled workers, including qualified scientists and engineers, the card will be particularly useful for researchers working in private industry, which is unlikely to follow the government accreditation process.

Scientists from outside the EU should benefit from the change, according to Louise McNally, the vice-rector of research at Pompeu Fabra University in Barcelona. But complications remain. According to Esther Alsina of the Catalan Researcher Mobility Node, a body that helps bring scientists from other countries to the Catalonia region, several aspects need to be fine-tuned by implementing regulations. For example, she says, the law requires that researchers be granted a visa if their salary at their host institution is above a certain amount. But the precise amount is still up for discussion. The Ministry of Labour and Immigration has until the middle of June to decide how to implement the regulations. "It is very important that the authorities establish realistic salary requirements according to the salaries that researchers earn," Alsina says.

The newly reformed law also stipulates that members of a researcher's immediate family will automatically obtain residency and work permits once the researcher is granted a visa. Under the current procedures, the scientist's family often needs to wait for a year before being granted a residence visa. This has deterred many non-EU scientists from coming to work in Spain.

"We urgently need to remove legal obstacles to hiring top scientists or we are going to lose talent to other European countries," says McNally.

Cristina Jiménez 